\title{
Kinerja Campuran Aspal Beton dengan Reclaimed Asphalt Pavement dari Jalan Nasional di Provinsi Jawa Timur
}

\author{
Performances of Asphalt Concrete Contain Reclaimed Asphalt \\ Pavement from National Road in East Jave Province
}

\author{
Ari Widayanti ${ }^{1, a)}$, Ria Asih Aryani Soemitro ${ }^{2, a)}$, Januarti Jaya Ekaputri ${ }^{2, b)}$ \& Hitapriya \\ Suprayitno $^{2, c)}$ \\ ${ }^{1)}$ Mahasiswa, Institut Teknologi Sepuluh Nopember Surabaya \\ ${ }^{2)}$ Dosen, Departemen Teknik Sipil, Institut Teknologi Sepuluh Nopember Surabaya
}

Koresponden : ${ }^{a)}$ ariwidayanti1973@gmail.com, ${ }^{b}$ ria@ce.its.ac.id, ${ }^{c}$ januartije@gmail.com \&

${ }^{d)}$ suprayitno.hita@gmail.com

\begin{abstract}
ABSTRAK
Jalan raya merupakan salah satu aset infrastruktur yang berperan dalam distribusi barang dan orang, perkembangan wilayah, ekonomi, sosial dan politik. Upaya pemeliharaan jalan dengan pengupasan material perkerasan di Provinsi Jawa Timur menghasilkan Reclaimed Asphalt Pavement (RAP) yang volumenya berkisar 50.000 $\mathrm{m}^{3} /$ tahun. Upaya pemanfaatan $R A P$ perlu dilakukan semaksimal mungkin sehingga menghasilkan campuran aspal beton yang memenuhi spesifikasi. Tujuan studi ini adalah memperoleh kinerja campuran aspal beton dengan penambahan $R A P$ dan strategi pemanfaatan $R A P$ untuk material perkerasan jalan. Metode yang digunakan adalah studi literatur dari peneliti terdahulu berbahan $R A P$ dari jalan nasional di Provinsi Jawa Timur. Hasil yang diperoleh adalah kinerja teknis campuran dengan $R A P$ memenuhi persyaratan Spesifikasi Bina Marga Tahun 2010 Revisi 3. RAP dapat digunakan pada lapisan AC-WC, AC-BC, AC-Base, dengan persentase penggunaan RAP sebesar 2040\%, RAP optimum sebesar 20-30\%, kadar aspal dalam RAP sebesar 3,78-4,63\%, VIM sebesar 4-4,825\%, VMA sebesar 14,941-15,867\%, VFB sebesar 65-87\%, Stabilitas Marshall sebesar 830,482-2655,22 kg, flow sebesar 3,26-5,74 mm, Stabilitas Marshall Sisa sebesar 90,1-92,65 kg, VIM in PRD 2,525-5,09\%. Strategi pemanfaatan RAP yaitu dengan menambahkan material lain berupa agregat atau aspal baru atau material lain yang ramah lingkungan untuk perkerasan jalan.
\end{abstract}

Kata Kunci : aset infrastruktur, jalan, kinerja, reclaimed asphalt pavement.

\section{PENDAHULUAN}

Pembangunan jalan di Indonesia menjadi prioritas dari pemerintah saat ini dan merupakan proyek strategis nasional yang sangat berperan dalam distribusi orang maupun barang, pertumbuhan ekonomi, sosial dan mendukung peningkatan kesejahteraan rakyat. Jalan merupakan salah satu aset infrastruktur transportasi yang mengalami perubahan akibat pembebanan lalu lintas, cuaca, lingkungan dan perilaku pengguna jalan. Perkembangan lalu lintas yang terjadi akhir-akhir ini mengakibatkan perkerasan jalan mengalami perubahan seiring dengan bertambahnya umur pelayanan jalan, kondisi cuaca dan lingkungan, serta perkembangan beban lalu lintas yang terjadi baik dari jenis kendaraan maupun volume lalu lintas. Bila lapisan perkerasan mencapai Indeks Permukaan Akhir, yang berarti perkerasan dapat dianggap sudah tidak memiliki nilai struktural lagi, maka dilakukan overlay/pelapisan 
ulang dengan perkerasan baru. Hal ini mengakibatkan bertambahnya elevasi jalan akibat proses pelapisan yang berulang-ulang (Suwantoro, 2010). Reclaimed Asphalt Pavement (RAP) adalah perkerasan aspal lama yang diperoleh dengan cara pengupasan perkerasan jalan dengan Cold Milling Machine atau Full Depth Removal (TRB, 2011). Upaya penanganan jalan dengan pengupasan perkerasan di Provinsi Jawa Timur menghasilkan RAP yang semakin bertambah sekitar $50.000 \mathrm{~m}^{3} /$ tahun (Budianto, 2009).

Manajemen aset infrastruktur jalan sangat diperlukan dalam rangka mengelola aset infrastruktur jalan agar dapat dimanfaatkan secara optimal. Penggunaan RAP sebagai bahan perkerasan jalan diharapkan merupakan salah satu langkah penghematan penggunaan material alam dan pengelolaan aset sehingga pembangunan dan pemeliharaan jalan dapat berjalan secara optimal.

Beberapa keuntungan pemanfaatan RAP adalah mengurangi penumpukan RAP sehingga tidak merusak lingkungan, efisiensi biaya, mengurangi penggunaan sumber alam, mengurangi laju kerusakan akibat penambangan dan penggalian (Budianto, 2009). Penggunaan RAP bermanfaat bagi kelestarian lingkungan (Widger dkk, 2012), mempunyai kemampuan untuk menghasilkan kinerja campuran yang optimum (Widger dkk, 2012), meningkatkan stabilitas (Parveez dkk, 2008) dan kinerja campuran (Pradyumna dkk, 2013), meningkatkan volumetrik, mekanik dan propertis campuran (Shen dkk, 2007), workability dan stabilitas yang lebih baik (Xiao dkk, 2009), mempengaruhi umur teknis jalan dan ketahanan terhadap kerusakan (Xiao dkk, 2007). Penggunaan RAP mengurangi kebutuhan untuk membuang perkerasan jalan lama, dan melestarikan ketersediaan material aspal dan agregat alam. Hal ini berdampak pada penghematan biaya produksi dan peningkatan keuntungan bagi masyarakat (TRB, 2011).

Pada sisi lain kelemahan RAP adalah gradasi RAP tidak masuk dalam kurva gradasi standar (Handayani, 2016; Kusmarini, 2012; Herawati, 2012), daktilitas tidak sesuai standar (Kusmarini, 2012; Harahab, 2013; Wibowo, 2012; Falevi, 2012; Herawati, 2012; Sujiartono, 2014), penetrasi tidak sesuai standar (Kusmarini, 2012; Harahab, 2013; Wibowo, 2012; Falevi, 2012; Herawati, 2012; Handayani, 2016; Sujiartono, 2014). Penggunaan RAP meningkatkan kerapuhan campuran perkerasan jalan (Parveez dkk, 2008). Pada campuran perkerasan jalan, tidak menghasilkan konsistensi perubahan pada penambahan propertis fisik campuran dalam aspek penetrasi, daktilitas, titik lembek. Dalam hal ini perlu dukungan penelitian dalam aspek mikrostruktur sehingga bisa meningkatkan kinerja teknis campuran perkerasan jalan (Sunil dkk, 2014). Karakteristik agregat dari RAP yang berasal dari 4 lokasi jalan Nasional di Provinsi Jawa Timur memenuhi semua syarat spesifikasi untuk agregat, sehingga dapat digunakan sebagai bahan campuran perkerasan jalan. Karakteristik aspal RAP memenuhi syarat spesifikasi, kecuali pada parameter penetrasi dan daktilitas. Dalam hal ini memerlukan material lain untuk dicampurkan dengan RAP sehingga dapat digunakan sebagai material perkerasan jalan (Widayanti dkk, 2017). Oleh karena itu studi tentang kinerja campuran perkerasan jalan dari RAP dan material lain perlu dilakukan sehingga dapat diketahui kekuatan campuran perkerasan aspal beton berbahan Reclaimed Asphalt Pavement. Penulisan studi ini bertujuan untuk:

- Memperoleh kinerja teknis campuran aspal beton dengan Reclaimed Asphalt Pavement dari jalan nasional di Provinsi Jawa Timur,

- Memperoleh strategi pemanfaatan Reclaimed Asphalt Pavement sebagai material perkerasan jalan.

\section{STUDI PUSTAKA}

\section{Kinerja Campuran Beraspal}

Sifat-sifat fisik aspal yang sangat mempengaruhi perencanaan, produksi dan kinerja campuran beraspal antara lain (Departemen Kimpraswil, 2002): 
1. Durabilitas. Sifat-sifat aspal berubah secara signifikan akibat oksidasi dan pengelupasan yang terjadi baik pada saat pencampuran, pengangkutan dan penghamparan campuran beraspal di lapangan. Kemampuan aspal untuk menghambat laju penuaan disebut Durabilitas Aspal. Pengujian durabilitas aspal untuk mengetahui seberapa baik aspal dalam mempertahankan sifat-sifat awalnya akibat proses penuaan. Pengujian kuantitatif yang biasa dilakukan dalam hal ini adalah penetrasi, titik lembek, kehilangan berat dan daktilitas. Pengujian ini dilakukan pada benda uji yang telah mengalami Thin Film Oven Test (TFOT) dan Rolling Thin Film Oven Test (RTFOT).

2. Adhesi dan Kohesi. Uji daktilitas aspal adalah uji kuantitatif yang secara tidak langsung dapat digunakan untuk mengetahui kemampuan partikel aspal keras untuk melekat satu sama lain. Aspal keras dengan nilai daktilitas yang rendah adalah aspal yang memiliki kohesi yang kurang baik dibandingkan dengan aspal dengan nilai daktilitas tinggi. Uji penyelimutan aspal terhadap batuan merupakan uji kualitatif lainnya untuk mengetahui adhesi aspal terhadap batuan.

3. Kepekaan terhadap Temperatur. Seluruh aspal bersifat termoplastik yaitu menjadi lebih keras bila temperatur menurun dan melunak bila temperatur meningkat. Kepekaan aspal untuk berubah sifat akibat perubahan temperatur dikenal sebagai kepekaan aspal terhadap temperatur. Penetrasi dan viskositas adalah sifat aspal yang peka terhadap temperatur. Pengetahuan tentang kepekaan aspal terhadap temperatur berguna untuk mengetahui temperatur yang tepat untuk aspal dan agregat dapat dicampur dan dipadatkan.

4. Pengerasan dan Penuaan. Proses penuaan karena oksidasi jangka pendek maupun jangka panjang menyebabkan terjadinya pengerasan pada aspal dan selanjutnya dapat meningkatkan kekakuan campuran beraspal sehingga dapat mempengaruhi kinerja campuran. Peningkatan kekakuan dapat meningkatkan ketahanan campuran terhadap deformasi permanen dan kemampuan untuk menyebarkan beban yang diterima. Akan tetapi hal ini dapat menyebabkan campuran menjadi lebih getas sehingga cepat retak dan akan menurunkan ketahanan terhadap beban berulang.

\section{Campuran Perkerasan Beraspal}

Campuran beraspal adalah kombinasi campuran antara agregat dan aspal. Aspal berperan sebagai pengikat atau lem antar partikel agregat, dan berperan sebagai tulangan. Sifat mekanis aspal dalam campuran diperoleh dari friksi dan kohesi dari bahan-bahan pembentuknya. Friksi agregat diperoleh dari ikatan antar butir agregat (interlocking), kekuatan agregat tergantung pada gradasi, tekstur permukaan, bentuk butiran dan ukuran agregat maksimum yang digunakan. Sedangkan sifat kohesinya diperoleh dari sifat-sifat aspal yang digunakan. Oleh sebab itu kinerja campuran beraspal sangat dipengaruhi oleh sifat-sifat agregat dan aspal, serta sifat-sifat campuran padat yang sudah terbentuk dari kedua bahan tersebut (Departemen Kimpraswil, 2002).

\section{Campuran Beraspal Panas}

Pekerjaan campuran beraspal panas mencakup pengadaan lapisan padat yang awet berupa lapis perata, lapis pondasi atau lapis aus yang terdiri dari agregat dan aspal yang dicampur secara panas di pusat instalasi pencampuran, serta menghampar dan memadatkan campuran di atas pondasi atau permukaan jalan yang telah disiapkan sesuai dengan spesifikasi dan memenuhi garis, ketinggian dan potongan memanjang yang ditunjukkan dalam gambar rencana. Semua campuran dirancang untuk menjamin bahwa asumsi rancangan yang terdiri dari kadar aspal, rongga udara, stabilitas, kelenturan dan keawetan sesuai dengan lalu-lintas rencana (Bina Marga, 2010). Terdapat beberapa jenis campuran beraspal panas, yaitu (Bina Marga, 2010):

1. Lapis Tipis Aspal Pasir (Sand Sheet, SS) Kelas A dan B. Terdiri dari dua jenis campuran, SS-A dan SS -B. Pemilihan SS-A dan SS-B tergantung pada tebal nominal minimum. 
Sand Sheet biasanya mememerlukan penambahan filler agar memenuhi kebutuhan sifatsifat yang disyaratkan.

2. Lapis Tipis Aspal Beton (Hot Rolled Sheet, HRS). Terdiri dari dua jenis campuran, HRS Pondasi (HRS-Base) dan HRS Lapis Aus (HRS-Wearing Course, HRS-WC) dan ukuran maksimum agregat masing- masing campuran adalah $19 \mathrm{~mm}$ dengan gradasi yang benarbenar senjang.

3. Lapis Aspal Beton (Asphalt Concrete, AC). Terdiri dari tiga jenis campuran, AC Lapis Aus (AC-Wearing Course/AC-WC), AC Lapis Antara (AC-Binder Course/AC-BC) dan AC Lapis Pondasi (AC-Base) dan ukuran maksimum agregat masing-masing campuran adalah $19 \mathrm{~mm}, 25,4 \mathrm{~mm}, 37,5 \mathrm{~mm}$ dengan gradasi yang menerus.

\section{Perencanaan Campuran Beraspal Panas Jenis Asphalt Concrete}

Tujuan perencanaan campuran beraspal panas adalah penentuan proporsi material untuk mencapai sifat akhir campuran yang diinginkan (NAPA, 1996) antara lain:

1. Stabilitas (Stability), adalah kemampuan campuran beraspal untuk menerima beban lalu lintas tanpa terjadi deformasi permanen seperti gelombang, alur dan lainnya.

2. Ketahanan terhadap Kelelahan (Fatigue Resistance), adalah ketahanan campuran beraspal dalam menerima beban berulang tanpa terjadinya kelelahan berupa alur dan retak.

3. Durabilitas (Durability), adalah kemampuan campuran beraspal untuk mempertahankan kualitasnya terhadap keausan yang terjadi akibat cuaca, air dan beban lalu lintas.

4. Ketahanan terhadap Air (Water Resistance), adalah ketahanan campuran terhadap air yang dapat menyebabkan kehilangan adhesi antara agregat dan aspal di lapisan permukaan.

5. Tahanan Geser (Skid Resistance) adalah kekesatan campuran sebagai lapisan permukaan sehingga kendaraan dapat lewat tanpa mengalami slip pada saat hujan atau kondisi basah.

6. Kemudahan Pelaksanaan (Workability) adalah kemudahan campuran untuk dihamparkan dan dipadatkan sehingga diperoleh tingkat kepadatan yang diinginkan.

\section{Sifat-sifat Campuran Aspal}

Sifat-sifat campuran aspal panas disampaikan pada Tabel 1 berikut ini.

\begin{tabular}{|c|c|c|c|c|}
\hline \multicolumn{5}{|c|}{ Laston/Asphalt Concrete } \\
\hline \multicolumn{2}{|l|}{ Sifat-sifat Campuran } & & & \\
\hline Jumlah tumbukan per-bidang & & \multicolumn{2}{|r|}{75} & 112 \\
\hline \multirow{2}{*}{$\begin{array}{c}\text { Rasio partikel lolos ayakan } 0,075 \mathrm{~mm} \\
\text { dengan kadar aspal efektif }\end{array}$} & Min & \multicolumn{3}{|c|}{1,0} \\
\hline & Maks & \multicolumn{3}{|c|}{1,4} \\
\hline \multirow{2}{*}{$\begin{array}{c}\text { Rongga dalam campuran/ } \\
\text { VIM (\%) }\end{array}$} & Min & \multicolumn{3}{|c|}{3,0} \\
\hline & Maks & \multicolumn{3}{|c|}{5,0} \\
\hline Rongga dalam agregat/VMA (\%) & Min & 15 & 14 & 13 \\
\hline Rongga terisi aspal/VFB (\%) & Min & 65 & 65 & 65 \\
\hline Stabilitas Marshall $(\mathrm{kg})$ & Min & & 800 & 1800 \\
\hline \multirow[t]{2}{*}{ Pelelehan/Flow (mm) } & Min & & 2 & 3 \\
\hline & Maks & & 4 & 6 \\
\hline $\begin{array}{l}\text { Stabilitas Marshall Sisa (\%) setelah } \\
\text { perendaman selama } 24 \mathrm{jam}, 60^{\circ} \mathrm{C}\end{array}$ & Min & \multicolumn{3}{|c|}{90} \\
\hline $\begin{array}{c}\text { Rongga dalam campuran pada Kepadatan } \\
\text { membal (refusal)/VIM PRD }(\%)\end{array}$ & Min & \multicolumn{3}{|c|}{2} \\
\hline
\end{tabular}

Sumber: Bina Marga (2010)

\section{PENGUMPULAN DATA}

Metode pengumpulan data dengan studi literatur dari penelitian tentang Reclaimed Asphalt Pavement dari jalan nasional di Provinsi Jawa Timur. 
(e)ISSN 2615-1847 $\quad$ (p) ISSN 2615-1839

Jurnal Manajemen Aset Infrastruktur \& Fasilitas - Vol. 2, No. 1, Maret 2018

\section{ANALISIS PENELITIAN}

Penilaian dan pengujian kinerja teknis Asphalt Concrete merujuk pada Spesifikasi Teknis Bina Marga Tahun 2010 Revisi 3. Hasil penelitian menunjukkan kesesuaian dan ketidak sesuaian pada masing-masing parameter dipresentasikan pada Tabel 2 berikut ini. 
Tabel 2 Kinerja Teknis Campuran Asphalt Concrete dengan Reclaimed Asphalt Pavement

\begin{tabular}{|c|c|c|c|c|c|c|c|c|c|c|c|}
\hline \multicolumn{2}{|c|}{ Kinerja Teknis } & \multicolumn{10}{|c|}{ Hasil Penelitian Terdahulu } \\
\hline & & \multicolumn{2}{|c|}{ Kusmarini } & \multicolumn{2}{|c|}{ Harahab } & Wibowo & Falevi & Herawati & Handayani & \multicolumn{2}{|c|}{ Sujiartono } \\
\hline \multicolumn{2}{|c|}{$\begin{array}{l}\text { Lokasi pengambilan } \\
\text { Reclaimed AsphaltPavement }\end{array}$} & $\begin{array}{l}\text { Gemekan- } \\
\text { Jombang }\end{array}$ & $\begin{array}{l}\text { Pandaan } \\
\text { - Malang }\end{array}$ & $\begin{array}{c}\text { Pandaan - } \\
\text { Malang }\end{array}$ & $\begin{array}{c}\text { Pilang- } \\
\text { Probolinggo }\end{array}$ & $\begin{array}{l}\text { Pandaan - } \\
\text { Malang }\end{array}$ & $\begin{array}{l}\text { Pandaan } \\
\text { - Malang }\end{array}$ & $\begin{array}{c}\text { Pilang - } \\
\text { Probolinggo }\end{array}$ & $\begin{array}{l}\text { Taman - Waru } \\
\text { Sidoarjo }\end{array}$ & \multicolumn{2}{|c|}{ Pilang - Probolinggo } \\
\hline Tipe perkerasan & - & $\begin{array}{c}\text { AC-WC } \\
\text { (Aspal Pen } \\
60-70)\end{array}$ & $\begin{array}{c}\text { AC-WC } \\
\text { (Aspal } \\
\text { Pen 60- } \\
70)\end{array}$ & $\begin{array}{c}\text { AC-WC } \\
\text { (Aspal Pen } \\
\text { 60-70 dan } \\
\text { Aspal } \\
\text { Modifikasi) }\end{array}$ & $\begin{array}{c}\text { AC-WC } \\
\text { (Aspal Pen } \\
\text { 60-70 dan } \\
\text { Aspal } \\
\text { Modifikasi) }\end{array}$ & $\begin{array}{c}\text { AC-BC } \\
\text { (Aspal Pen } \\
60-70)\end{array}$ & $\begin{array}{l}\text { AC -WC } \\
\text { (Aspal } \\
\text { Pen 60- } \\
70 \text { ) }\end{array}$ & $\begin{array}{c}\mathrm{AC}-\mathrm{BC} \\
\text { (Aspal Pen } \\
60-70)\end{array}$ & $\begin{array}{c}\text { AC-BC } \\
\text { (Aspal Pen 60- } \\
70)\end{array}$ & $\begin{array}{c}\text { AC-BC } \\
\text { (Aspal } \\
\text { Modifikasi } \\
\text { Asbuton- } \\
\text { BNA } \\
\text { Blend) } \\
\end{array}$ & $\begin{array}{l}\text { AC-Base } \\
\text { (Aspal } \\
\text { Modifikasi } \\
\text { Asbuton- } \\
\text { BNA } \\
\text { Blend) } \\
\end{array}$ \\
\hline Persentase RAP & $\%$ & $30 ; 40$ & $20 ; 30 ; 40$ & $25 ; 30$ & $25 ; 30$ & $25 ; 30$ & $25: 30$ & $20 ; 30$ & 20 & \multicolumn{2}{|c|}{$25 ; 35 ; 40$} \\
\hline $\begin{array}{l}\text { Persentase RAP } \\
\text { optimum }\end{array}$ & $\%$ & 30 & 20 & 25 & 25 & 25 & 25 & 20 & 20 & 25 & 25 \\
\hline $\begin{array}{l}\text { Kadar aspal } \\
\text { dalam RAP }\end{array}$ & $\%$ & 4,6 & 3,78 & 4,63 & 4,15 & 4,63 & 4,63 & 4,5 & 4 & 4,18 & 4,18 \\
\hline $\begin{array}{l}\text { Kadar aspal } \\
\text { optimum }\end{array}$ & $\%$ & 5,8 & 5,9 & 6,05 & 6,15 & $5,8-6,1$ & 6,35 & $5,6-6,2$ & 6,4 & 5,9 & 5,65 \\
\hline $\begin{array}{l}\text { Rongga dalam } \\
\text { campuran (VIM) }\end{array}$ & $\%$ & 4,60 & 4,61 & 4,69 & 4,53 & 4,47 & $4-4,7$ & 2,273 & 3,906 & $\begin{array}{l}3,794- \\
5,057\end{array}$ & $\begin{array}{l}4,308- \\
4,825\end{array}$ \\
\hline $\begin{array}{l}\text { Rongga dalam } \\
\text { agregat (VMA) }\end{array}$ & $\%$ & $\begin{array}{l}15,71- \\
17,24\end{array}$ & $\begin{array}{l}16,08- \\
17,46\end{array}$ & 17,23 & 17,25 & $\begin{array}{l}18,07- \\
18,58\end{array}$ & $\begin{array}{l}17,5- \\
18,2\end{array}$ & 14,941 & 15,867 & $\begin{array}{l}15,055- \\
16,219\end{array}$ & $\begin{array}{l}16,393- \\
18,016\end{array}$ \\
\hline $\begin{array}{l}\text { Rongga terisi } \\
\text { aspal (VFB) }\end{array}$ & $\%$ & $\begin{array}{l}71,72- \\
89,43\end{array}$ & $\begin{array}{l}71,91- \\
89,5\end{array}$ & 72,79 & 73,73 & $68,8-82,20$ & $65-87$ & 84,816 & 75,389 & $\begin{array}{l}66,575- \\
76,053\end{array}$ & $\begin{array}{l}70,566- \\
76,095\end{array}$ \\
\hline $\begin{array}{l}\text { Stabilitas } \\
\text { Marshall }\end{array}$ & $\mathrm{kg}$ & $\begin{array}{l}1488,2- \\
1705,94\end{array}$ & $\begin{array}{c}1268,73- \\
1477,72\end{array}$ & 1370,05 & 1801,25 & $\begin{array}{c}1150- \\
1324,3\end{array}$ & $\begin{array}{l}1300- \\
1500\end{array}$ & 882,750 & 830,482 & $\begin{array}{l}1129,35- \\
1335,66\end{array}$ & $\begin{array}{l}2509,94- \\
2655,22\end{array}$ \\
\hline Pelelehan/Flow & $\mathrm{mm}$ & $3,3-3,98$ & $3,26-3,90$ & 3,89 & 3,65 & $4,23-5,20$ & $4,3-4,6$ & 3,75 & 3,8 & $3,43-3,73$ & $5,24-5,74$ \\
\hline $\begin{array}{l}\text { Stabilitas } \\
\text { Marshall Sisa (\%) }\end{array}$ & $\%$ & $\begin{array}{l}90,14- \\
92,12 \\
\end{array}$ & $\begin{array}{l}90,18- \\
91,31 \\
\end{array}$ & 91,2 & 91,45 & $90,1-92,5$ & $\begin{array}{l}92,8- \\
95,3\end{array}$ & 91,45 & 90,91 & $\begin{array}{l}90,46- \\
92,05\end{array}$ & $90-92,65$ \\
\hline $\begin{array}{l}\text { Rongga dalam } \\
\text { campuran }(\%)- \\
\text { VIM PRD }\end{array}$ & $\%$ & 3,57 & $2,57-3,61$ & 2,86 & 2,525 & $2,66-5,09$ & - & 0,603 & 0,495 & $\begin{array}{l}2,760- \\
4,904\end{array}$ & 4,047 \\
\hline
\end{tabular}

Sumber: Prosiding Seminar Nasional dan Tesis ITS Surabaya (2012-2016). 
Berdasarkan Tabel 2 diperoleh karakteristik volumetrik (VIM/Void in Mix, VMA/Void Mineral Aggregate dan VFB/Void Fill Bitumen) menunjukkan hasil yang memenuhi spesifikasi yaitu VIM sebesar 4-4,825\%, VMA sebesar 14,941-15,867\%, VFB sebesar 65$87 \%$. Karakteristik volumetrik merupakan faktor yang mempengaruhi durabilitas perkerasan (NAPA, 1996). VMA harus menyediakan cukup ruang untuk VIM dan VFB. Nilai VIM harus berada pada rentang tertentu yang disyaratkan agar tidak terlalu besar sehingga menyebabkan terjadinya oksidasi aspal, atau terlalu kecil sehingga tidak cukup ruang untuk pengaliran aspal akibat pembebanan lalu lintas. Nilai VFB dan gradasi menentukan tebal aspal film yang berpengaruh pada kecepatan oksidasi aspal dan penyerapan air. Nilai VIM dan VMA berbanding terbalik dengan nilai kepadatan yang dicapai oleh campuran. Semakin tinggi kepadatan campuran berarti semakin besar rongga yang terisi oleh aspal atau filler (VFB) sehingga memperkecil nilai VIM dan VMA. Nilai kepadatan meningkat (sampai kadar aspal tertentu) disebabkan oleh peningkatan kadar aspal campuran untuk melumasi partikel dalam campuran sehingga upaya pemadatan berlangsung lebih baik.

Nilai VIM pada kepadatan membal memenuhi persyaratan kecuali pada 2 penelitian (Herawati, 2012 dan Handayani, 2016) dengan nilai rendah sekali yaitu dibawah 1. Hal ini kemungkinan terjadi karena nilai kepadatan yang terlalu tinggi. Spesifikasi Bina Marga 2010 Revisi 3 mensyaratkan nilai VIM PRD minimum sebesar 2\% untuk mempertahankan durabilitas campuran tetap baik pada kondisi membal karena pemadatan oleh lalu lintas lintas berat dan padat dengan temperatur tinggi di lapangan. Nilai VIM yang rendah menyebabkan lapisan aspal meleleh keluar yang dinamakan bleeding, apabila ada beban lalu lintas yang menambah pemadatan lapisan.

Stabilitas adalah besarnya beban maksimum yang dapat dicapai oleh campuran yang dinyatakan dalam satuan beban dan merupakan indikator kekuatan lapis perkerasan dalam memikul beban lalu lintas. Nilai stabilitas untuk semua campuran dapat dicapai dan memenuhi spesifikasi standar berkisar antara Stabilitas Marshall sebesar 830,482-2655,22 kg. Hal ini juga sangat tergantung pada lapisan perkerasan yang direncanakan mencakup $A C$ Wearing Course, AC-Binder Course atau AC Base Course.

Nilai pelelehan/flow sebesar 3,26-5,74 $\mathrm{mm}$. Nilai pelelehan yang tinggi menunjukkan campuran yang bersifat plastis. Faktor yang menyebabkan campuran plastis diperkirakan adalah viskositas tinggi dan penetrasi rendah. Viskositas aspal RAP yang lebih besar dan penetrasi RAP yang lebih kecil dibandingkan viskositas dan penetrasi aspal menyebabkan semakin tinggi persentase RAP maka semakin meningkatkan flow/pelelehan yang terjadi.

Hasil penelitian sebelumnya menyatakan bahwa agregat RAP tidak masuk dalam amplop gradasi sesuai dengan spesifikasi yang disyaratkan. Sifat fisik aspal RAP memenuhi spesifikasi kecuali pada nilai penetrasi dan daktilitas. Aspal keras dengan nilai daktilitas yang rendah adalah aspal yang memiliki kohesi yang kurang baik dibandingkan dengan aspal dengan nilai daktilitas yang tinggi. Kemampuan aspal untuk menghambat laju penuaan disebut Durabilitas Aspal. Pengujian durabilitas aspal untuk mengetahui seberapa baik aspal dalam mempertahankan sifat-sifat awalnya akibat proses penuaan. Pengujian kuantitatif untuk mengetahui durabilitas aspal adalah pengujian penetrasi, titik lembek, kehilangan berat dan daktilitas.

Seluruh aspal bersifat termoplastik yaitu menjadi lebih keras bila temperatur menurun dan melunak bila temperatur meningkat. Kepekaan aspal untuk berubah sifat akibat perubahan temperatur dikenal sebagai kepekaan aspal terhadap temperatur. Penetrasi dan viskositas adalah sifat aspal yang peka terhadap temperatur. Pengetahuan tentang kepekaan aspal terhadap temperatur berguna untuk mengetahui temperatur yang tepat bagi aspal dan agregat dapat dicampur dan dipadatkan. 
(e)ISSN 2615-1847 $\quad$ (p) ISSN 2615-1839

Jurnal Manajemen Aset Infrastruktur \& Fasilitas - Vol. 2, No. 1, Maret 2018

\section{KESIMPULAN}

Berdasarkan hasil pengumpulan data dan analisis yang sudah dilakukan maka kesimpulan yang diperoleh adalah:

- Reclaimed Asphalt Pavement dari jalan nasional di Provinsi Jawa Timur dapat digunakan pada lapisan AC-WC, AC-BC, AC-Base, dengan persentase penggunaan RAP sebesar 2040\%, RAP optimum sebesar 20-30\%, kadar aspal dalam RAP sebesar 3,78-4,63\%, VIM sebesar 4-4,825\%, VMA sebesar 14,941-15,867\%, VFB sebesar 65-87\%, Stabilitas Marshall sebesar 830,482-2655,22 kg, flow sebesar 3,26-5,74 mm, Stabilitas Marshall Sisa sebesar 90,1-92,65 kg, VIM in PRD 2,525-5,09\%. Kinerja campuran Asphalt Concrete dengan Reclaimed Asphalt Pavement menunjukkan hasil sesuai dengan standar kecuali nilai VIM pada PRD. Hal ini kemungkinan terjadi karena nilai kepadatan yang terlalu tinggi. Nilai VIM yang kecil menyebabkan lapisan aspal meleleh keluar yang dinamakan bleeding, apabila ada beban lalu lintas yang menambah pemadatan lapisan.

- Strategi pemanfaatan Reclaimed Asphalt Pavement untuk material perkerasan jalan yaitu perlu menambahkan material lain yang baru atau material lain yang ramah lingkungan.

Berdasarkan pada hasil pengumpulan data, analisis dan kesimpulan yang diperoleh, maka saran yang dapat disampaikan adalah:

- Perlu penelitian lebih lanjut dengan memanfaatkan material lain yang dapat mengatasi kelemahan penggunaan Reclaimed Asphalt Pavement untuk lapisan perkerasan jalan.

Catatan. Penulisan studi ini didukung dengan beberapa studi literatur yang bertujuan untuk mengetahui kinerja Asphalt Concrete dengan Reclaimed Asphalt Pavement. Kami menyampaikan terima kasih kepada para peneliti yang karyanya menjadi rujukan dalam penulisan studi ini.

\section{DAFTAR PUSTAKA}

Bina Marga. (2010). Spesifikasi Umum Bina Marga Tahun 2010 Revisi 3. Direktorat Jenderal Bina Marga Kementrian Pekerjaan Umum. Jakarta.

Budianto, H. (2009). Menuju Jalan yang Andal. PT. Cakra Daya Sakti. Surabaya.

Departemen Kimpraswil (2002). Manual Pekerjaan Campuran Beraspal Panas. Departemen Pemukiman dan Prasarana Wilayah. Direktorat Jenderal Prasarana Wilayah. Jakarta.

Falevi, R. (2012). “Optimalisasi Penggunaan Reclaimed Asphalt Pavement (RAP) sebagai Bahan Campuran Beraspal Panas (Asphaltic Concrete) Tipe AC-Wearing Course (ACWC) Gradasi Halus dengan Menggunakan Aspal Pen 60-70 Variasi Abrasi Agregat Baru (Studi Kasus Jalan Nasional Pandaan - Malang)". Tesis Pasca Sarjana. Institut Teknologi Sepuluh Nopember (ITS). Surabaya.

Handayani, R. (2016). “Analisa Penggunaan Reclaimed Asphalt Pavement (RAP) sebagai Bahan Campuran Beraspal Panas Tipe Asphalt Concrete-Binder Course (ACBC) dengan Menggunakan Fly Ash (Studi Kasus Ruas Jalan Taman Waru)". Tesis Pasca Sarjana. Institut Teknologi Sepuluh Nopember (ITS). Surabaya.

Harahab, S. Soemitro, R.A.A, Budianto, H. (2013). "Optimalisasi Penggunaan Reclaimed Asphalt Pavement (RAP) sebagai Bahan Campuran Beraspal Panas (Asphaltic Concrete) Tipe AC-Wearing Course (AC-WC) Gradasi Kasar dengan Aspal Pen 60-70 dan Aspal Modifikasi Jenis TRS 55 (Studi Kasus Jalan Nasional Pandaan-Malang dan Jalan Nasional Pilang-Probolinggo)". Prosiding Seminar Nasional Pascasarjana XIII ITS, Surabaya 15 Agustus 2013, ISBN No. 978-979-96700-6-9.

Herawati, N., Soemitro, R.A.A., Budianto, H. (2012). "Analisis Penentuan Komposisi Optimal Penggunaan Reclaimed Asphalt Pavement (RAP) sebagai Bahan Campuran Beraspal Panas (Asphaltic Concrete) Menggunakan Aspal Modifikasi (Studi Kasus Jalan Pilang - Probolinggo)". Prosiding Seminar Nasional Aplikasi Teknologi Prasarana Wilayah (ATPW) Surabaya, 11 Juli 2012. ISSN 2301-6752, hal. F-1. 
Kusmarini, E.P., Soemitro, R.A.A., Budianto, H. (2012). “Analisis Penggunaan Reclaimed Asphalt Pavement (RAP) dan Aspal Pen 60 - 70 sebagai Bahan Campuran Beraspal Panas (Asphaltic Concrete ) (Studi Kasus Ruas Jalan Gemekan - Jombang dan Pandaan - Malang)". Prosiding Seminar Nasional Aplikasi Teknologi Prasarana Wilayah (ATPW) Surabaya, 11 Juli 2012, ISSN 2301-6752, hal. F-5 - F-10.

NAPA (1996). Hot Mix Asphalt Materials Mixture Design and Construction. National Asphalt Pavement Association. NAPA Education Foundation. Maryland.

Parveez, Prateek, Srikanta, Yathiraj, Konnur, Dinesh, (2008). "Study on the Effect of Reclaimed Asphalt Pavement (RAP) on the Mechanical Behaviour of Hot Mix Asphalt". India.

Pradyumna, T Anil. Mittal, Abhishek, Jain, P.K. (2013). "Characterization of Reclaimed Asphalt Pavement (RAP) for Use in Bituminous Road Construction”. Procedia-Social and Behavioral Sciences 104, hal. 1149-1157.

Shen, J., Amirkhanian, S., Aune, J.M. (2007). "Effects of Rejuvenatin Agents of Superpave Mixtures Containing Reclaimed Asphalt Pavement". Journal of Materials in Civil Engineering. ASCE. May. 2007.

Sujiartono, A. (2014). Optimalisasi Penggunaan Reclaimed Asphalt Pavement (RAP) sebagai sebagai Bahan Campuran Beraspal Panas (Asphaltic Concrete) Tipe AC-Binder Course (AC-BC) dan AC-Base Course (AC-Base) dengan Menggunakan Aspal Modifikasi Asbuton (BNA-Blend) (Studi Kasus Jalan Nasional Pilang-Probolinggo). Tesis Pasca Sarjana. Institut Teknologi Sepuluh Nopember Surabaya.

Sunil, S. Mallesh, K.M., Chandrasekaraiah. (2014). "Experimental Investigation on The Perfomance of Bituminous Mixes wth Reclaimed Asphalt Pavement (RAP) Materials (Case Study Tumkur to Chidradurga-NH4)". IJRET: International Journal of Research in Engineering Technology. Volume: 03 Special Issue: 06. May 2014, pp. 297-303.

Suwantoro (2010). "Optimalisasi Penggunaan Material Hasil Cold Milling untuk Daur Ulang Lapisan Perkerasan Beton Aspal Tipe AC (Asphaltic Concrete)". Tesis Pasca Sarjana. Institut Teknologi Sepuluh Nopember Surabaya.

TRB (2011). A Manual for Design of Hot Mix Asphalt with Commentary. National Cooperative Highway Research Program. NCHRP Report 673. Transportation Research Board. Washington DC.

Wibowo, H.W. (2012). "Optimalisasi Penggunaan Reclaimed Asphalt Pavement (RAP) sebagai Material Campuran pada Asphaltic Concrete Tipe AC-BC dan AC-Base dengan Pen 60-70 (Studi Kasus Jalan Nasional Pandaan - Malang)". Jurusan Teknik Sipil, Institut Teknologi Sepuluh Nopember, Surabaya.

Widayanti, A., Soemitro, R.A.A., Ekaputri, J.J., Suprayitno, H. (2017). "Karakteristik Material Pembentuk Reclaimed Asphalt dari Jalan Nasional di Provinsi Jawa Timur". Jurnal Manajemen Aset Infrastruktur dan Fasilitas, Volume 1, No. 1, Desember 2017, ISSN 2615-1847, hal. 11-22.

Widger, A., Skilnick, F., Zabolotnii, E. (2012). Utilization of Recycled Asphalt in Cold Mixes and Cold In-Place Recycling Processes-Guidelines. Engineer-In-Training Clifton Associated Ltd. Communities of Tomorrow, Leveraged Municipal Innovation Fund.

Xiao, F., Amirkhanian, S.N., Shen, J., Putman, B. (2009). "Influences of Crumb Rubber Size and Type on Reclaimed Asphalt Pavement (RAP) Mixtures". Journal Construction and Building Materials 23, hal.1028-1034.

Xiao, F., Amirkhanian, Serji, J., Hsein, C. (2007). "Rutting Resistance of Rubberized Asphalt Concrete Pavements Containing Reclaimed Asphalt Pavement Mixtures”, Journal of Materials in Civil Engineering, ASCE, June 2007, hal. 475-483. 